\title{
PERCEPTIONS OF ENTREPRENEURSHIP IN MALAWI: A COUNTRY CONTEXT UNDERSTANDING OF ENTREPRENEURSHIP
}

\author{
Charles Mwatsika \\ Management Studies Department, Malawi University of Business and Applied Sciences, Blantyre, Malawi \\ Email: cmwatsika@mubas.ac.mw
}

Received: 7 July 2021. Revision received: 23 August 2021. Accepted: 20 September 2021

\begin{abstract}
Entrepreneurship is considered a strategy for economic development, but other scholars found that it does not bring economic growth in developing countries. Although entrepreneurship has multiple perspectives, there is a lack of knowledge about prevailing perceptions and activities undertaken in developing countries, especially in Sub-Saharan Africa. The purpose of this study was to measure the perceptions of entrepreneurship in Malawi to have country context knowledge of the concept that guides what is undertaken as entrepreneurship. A cross-sectional survey of 337 enterprise owners and managers was undertaken using a questionnaire. Participants were requested to provide their top-of-the-mind definitions of entrepreneurship and activities their enterprises had undertaken which were considered entrepreneurial. Analyses of definitions and activities undertaken were used to draw out perceptions of entrepreneurship. The study found that starting and managing one's own business for profit, creating jobs, and being self-employed is the prevailing understanding of entrepreneurship in Malawi. The study further found low innovation among enterprises. Although the perceptions found reflect classical economic perspectives, they are inadequate to ignite economic development because of a lack of focus on innovation. The findings imply that understanding a concept is important in practice. Therefore, stakeholders are encouraged to appraise their knowledge about entrepreneurship to align with theories where entrepreneurship is the driver of business growth and economic development. Further studies are required on the relationships between perceptions of entrepreneurship, activities undertaken, and economic development to advance entrepreneurial knowledge in Sub-Saharan Africa.
\end{abstract}

KEYWORDS: Entrepreneurship, perceptions, entrepreneurial activities, Malawi

JEL CLASSIFICATION: L20, L26, L29

Reference: Mwatsika, C. (2021). Perceptions of entrepreneurship in Malawi: A country context understanding of entrepreneurship. International Journal of Entrepreneurial Knowledge, 9(2), 49-62. doi: 10.37335/ijek.v9i2.134

\section{INTRODUCTION}

Schumpeter (1934) placed entrepreneurship at the centre of economic development theory, and empirical studies such as Nitu-Antonie et al. (2017) and Chen (2014) support that a positive and significant relationship exists between entrepreneurship and economic growth. Entrepreneurship is therefore considered a strategy for economic development across countries. It is also noted that entrepreneurship has multiple perspectives (Bula, 2012). But the creation of a new enterprise, business, or company seems both an explicit and implicit reference to the concept. Because most enterprises start small and grow over time, the prevalence of micro, small and medium enterprises (MSMEs) is presumed as the manifestation of entrepreneurial behaviour in an economy. MSMEs are thereby perceived synonymously with entrepreneurship (Henrekson \& Sanandaji, 2014; Acs \& Virgill, 2009). Because MSMEs reflect entrepreneurship and constitute a large segment of businesses, they are considered the driver of economic development in both developed and developing countries (Ruchkina et al., 2017; Kuzubikova \& Zoubkova, 2016). Malawi is not an exception.

Since attaining its independence in 1964, Malawi has suffered perpetually from poverty and unemployment. Over half $(70.9 \%)$ of its population lives below the poverty line of $\$ 1.90$ per day, and the unemployment rate is high at 20.4 percent (Finscope, 2019; Government of Malawi (GOM), 2017a). The 


\section{INTERNATIONAL JOURNAL OF ENTREPRENEURIAL KNOWLEDGE}

Issue 9, volume 2, ISSN 2336-2960 (Online)

www.ijek.org

country's economy relies on agriculture which contributes 30 percent to Gross Domestic Product (GDP), employs 64 percent of the labour force, and generates 80 percent of foreign exchange earnings (Finscope, 2019). There have been efforts to diversify the economy from agriculture to manufacturing (industrial development), starting with the Structural Adjustment Programmes (SAP) implemented in the 1980s. The MSME sector was identified as the driver of the economic development agenda. As such, institutions were established to provide; access to start-up finance, enterprise management training, business infrastructure, quality standards, promote trade and investment, access to markets and information, business development services, and to coordinate policy for the development of the MSME sector (Masten \& Kandoole, 1997).

Finscope (2019) provides a highlight of the MSME sector in Malawi. There are 1.6 million MSMEs in the country which are concentrated in the three cities of Blantyre, Lilongwe, and Mzuzu. Micro enterprises are the largest component $(74 \%)$ followed by small enterprises $(23 \%)$. There are few mediumsized enterprises $(3 \%)$ in the country. Sole proprietorship $(86 \%)$ is the most prevalent form of organisation within the MSME sector when compared to limited liability company $(8 \%)$ and other $(6 \%)$ forms of organisation. The largest proportion of MSMEs is informal businesses (89\%), whereas only 11 percent of MSMEs are formal businesses. It is also important to note that most MSME businesses are directly linked to agriculture. Overall, the MSME sector contributes 44 percent to GDP and employs 24 percent of the labour force (Finscope, 2019).

However, the prevailing high levels of poverty and unemployment bring about realization, among practitioners, of inadequacies of the MSME sector to create more quality jobs and ignite economic development as expected, despite the perceived potential of the sector. The context of MSMEs in Malawi reflects what Lafuente et al. (2018) call the entrepreneurship paradox. The country has a high total earlystage entrepreneurial activity (TEA) rate of 35.6 percent (Dalious et al., 2012) and 13 percent of the adult population (aged 18 to 64) is estimated to own a business (Finscope, 2019). Nonetheless, the country does not attain sustained economic growth (GOM, 2017a). This situation supports findings by Zaki and Rashid (2016), Stam and van Stel (2009) and van Stel et al. (2005) that entrepreneurship does not bring economic growth in developing countries but in developed and transition countries. Attempts to explain the phenomenon focus on factors that inhibit MSME sector growth. Doing Business reports of the World Bank Group consistently highlight binding constraints in the environments for business in developing countries (World Bank Group, 2020). In Malawi, these challenges include: lack of access to credit, high cost of credit, weak institutional and regulatory framework, weak value chain integration, poor business infrastructure, high cost of infrastructural services, high taxes, weak private sector support institutions, corruption, lack of skilled labour force and a weak culture of entrepreneurship (GOM, 2012). Entrepreneurship development initiatives have focused on solving these challenges for decades, with some improvements noted by the Doing Business report on Malawi (World Bank Group, 2020). Although policy, institutional reforms and various strategies are undertaken (Finscope, 2019; GOM, 2017b; 2012) to redouble efforts towards MSME support, the problem is that they are a repeat of what has failed over the past decades i.e. the focus on microfinance, creation of value chains, enterprise management training, infrastructure development (markets, roads) et cetera.

A gap of scholarly interest was therefore spotted to investigate the understanding of entrepreneurship in the country and activities undertaken by MSMEs which are perceived as entrepreneurial. That was necessary because entrepreneurship has no commonly agreed definition or theory (Henrekson \& Sanandaji, 2014). Multiple perceptions represent gaps in knowledge about a concept which would lead to differences in activities undertaken. Sheriff et al. (2016) assert that there is a lack of knowledge about types and rates of entrepreneurship undertaken in developing countries. Not many studies have investigated the perceptions of entrepreneurship and entrepreneurial activities undertaken by MSMEs in Malawi, which would allow a reflection on the consequences of the perceptions and activities undertaken on economic growth. 


\section{INTERNATIONAL JOURNAL OF ENTREPRENEURIAL KNOWLEDGE}

Issue 9, volume 2, ISSN 2336-2960 (Online)

www.ijek.org

The purpose of the study was therefore, to measure the perceptions of entrepreneurship in enterprises in Malawi in order to have country context knowledge of the concept which guides what is undertaken as entrepreneurship. The study was motivated by lack of knowledge about entrepreneurship in developing countries and the one sided focus on the entrepreneurial ecosystem in explaining the entrepreneurship paradox. It was an attempt to respond to questions on meanings of entrepreneurship among MSMEs in Malawi and activities they undertake based on the understanding of the concept. The findings would allow a reflection on the prevailing knowledge about entrepreneurship against theory and best practice and also inform future studies about entrepreneurship in developing countries. This was important because efforts to enhance the performance of entrepreneurial ecosystems have existed in Malawi and other developing countries in Sub Saharan Africa for a long period. However, despite some improvements, the higher TEA rates (Dalious et al., 2012), and growing number of MSMEs, in Malawi for instance (Finscope, 2019), expected economic development and job creation is not achieved (Meressa, 2020; GOM, 2017a; Cassim et al., 2014). That raised questions on the understanding of entrepreneurship and activities undertaken. The study therefore assessed perceptions of entrepreneurship by asking respondents to explain or define entrepreneurship from the top-of-their-minds (Lee, 2011) and to explain the activities their enterprises had undertaken which were considered entrepreneurial. Innovations carried out by the enterprises in the categories of new goods and services, new methods of production, new markets and new ways of organisation were also measured in order to reflect on entrepreneurship from the neoclassical economic perspective.

In the following sections, the theoretical perspectives of entrepreneurship and perceptions of entrepreneurship in developed countries are reviewed. Thereafter, the methodology used to carry out the study is presented before the results on the country context understanding of entrepreneurship in Malawi are presented and discussed. Finally, the conclusion is drawn with a highlight on implications of the findings, their limitations and areas for future research on the topic.

\section{LITERATURE REVIEW}

\subsection{Theoretical perspectives of entrepreneurship}

Since Cantillon (1755) originated the term entrepreneurship, it has had multiple perspectives as the understanding of the concept evolved. Cantillon (1755) conceptualises entrepreneurship as an undertaking by individuals alert to market imbalances who procure raw materials at certain prices to rework them up and resell at uncertain prices for a profit. Entrepreneurship in this early theory is considered an important economic activity which moves markets towards the equilibrium point. Because individuals identified as entrepreneurs were essentially self-employed and perceived as undertakers of risk, entrepreneurship is commonly perceived as self-employment which involves risk. Nonetheless, this emergent perception does not capture the meaning of the concept.

Advancing the concept, Say (1816) theorises entrepreneurship as the function of uniting factors of production to produce goods and services, and the entrepreneur as the coordinator of the factors of production (land, labour and capital). Say (1816) extends the aspect of procuring raw materials in Cantillon's (1755) theory to that of bringing together all factors of production in order to produce goods and services which nonetheless reflects the same meaning of entrepreneurship. However, with the advancement of modern industry, Harbison (1956) notes that identification of the entrepreneur with an individual person is unreasonable because there are a number of individuals who perform entrepreneurial functions within an enterprise. But setting up organisation was central to production of goods and services. Therefore Harbison (1956) theorises entrepreneurship as the skill to build an enterprise (set up organisation) which produces goods and services. Entrepreneurship is therefore perceived and defined 


\section{INTERNATIONAL JOURNAL OF ENTREPRENEURIAL KNOWLEDGE}

Issue 9, volume 2, ISSN 2336-2960 (Online)

www.ijek.org

by some scholars as the creation or founding of an enterprise, business or organisation which produces goods and services (Scarborough, 2013; Dollinger, 2008). This is the common emergent perception of entrepreneurship from the classical economic theory although it does shift the original focus of the concept away from creation of new goods and services to the new business or organisation.

Schumpeter (1934) brought a definitive perspective of modern entrepreneurship. He developed an entirely new economic theory of entrepreneurship that is focused on innovative and discontinuous change. He perceives entrepreneurship as carrying out new combinations of resources (factors of production) to create innovations which forever disrupt markets and bring new disequilibrium. His theory highlights the point an activity is recognised as entrepreneurial by focusing on magnitude of newness of creation (innovation). Schumpeter (1934) classifies innovations into new goods and services, new methods of production, new markets, new sources of supply of raw materials and new ways of organisation of any industry (p.66). He asserts that carrying out innovations is entrepreneurship and the individual whose function is to carry out innovations, is called an entrepreneur. This is the theory of entrepreneurship which Schumpeter (1934) places at the centre of his theory of economic development. However, there is some discrepancy in the understanding of the term 'new organisation'. Schumpeter (1934) refers a new way of organisation to a new pattern, order or method of organisation which would render other approaches to organisation redundant when introduced. From classical economic theory (Harbison, 1956; Say, 1816), a 'new organisation' refers to a new entity which produces goods and services even if it does not bring new patterns or methods of organisation or other innovations to the market. Therefore, some of the new organisations recorded in entrepreneurship surveys may not represent entrepreneurship in Schumpeterian sense. Schumpeter's (1934) theory nonetheless, broadens the outputs of entrepreneurship. Entrepreneurship is not limited to the creation of new ways of organisation but all other categories of innovations. The perception of entrepreneurship that is based on one category of innovations is consequently deemed narrow and limiting to the understanding of the concept. Schumpeter's (1934) theory furthermore expands the context of the entrepreneur from the individual who carries out innovations to all who actually fulfil the function by which he defines the concept, even if they are employees of a company. Schumpeter (1934) asserts that it is carrying out innovations which make up the entrepreneur.

The other common perspective of entrepreneurship is that it is a process of opportunity identification, evaluation and exploitation. Opportunities in this perspective refer to 'entrepreneurship opportunities' whose exploitation would result in the creation of innovations (Shane \& Venkataraman, 2000). From this perspective, opportunities are a key construct and entrepreneurs are perceived as individuals with opportunity alertness (Kirzner, 1973). It further recognises that carrying out incremental innovations (Coccia, 2006) is also entrepreneurship rather than only pioneering or discontinuous innovations which Schumpeter's (1934) theory focuses upon. Entrepreneurship is further perceived as a management function through which judgmental decisions are undertaken to marshal scarce resources to produce goods and services (Kirby, 2003). However, because the majority of times management is about the efficient running of processes to achieve set goals, Schumpeter (1934) argues that management is not a salient point in defining the entrepreneurial function.

This review shows multiple perceptions of entrepreneurship. These are: identifying market discrepancies and procuring raw materials to rework them up and resell at a profit (Cantillon, 1755); coordinating factors of production to produce goods and services (Say, 1816); creating enterprises that produce goods and services (Harbison, 1956); carrying out innovations (Schumpeter, 1934); identifying, evaluating and exploiting opportunities to create new goods and services (Shane \& Venkataraman, 2000) and marshalling scarce resources (Kirby, 2003). Starting a new business or enterprise is a commonly implied meaning of the concept among scholars. It is Schumpeter's (1934) theory however, which underpins the modern understanding of the concept (Henrekson \& Sanandaji, 2014) and places entrepreneurship at the centre of economic development theory. The emergent perceptions such as self-employment, undertaking risky 


\section{INTERNATIONAL JOURNAL OF ENTREPRENEURIAL KNOWLEDGE}

Issue 9, volume 2, ISSN 2336-2960 (Online)

www.ijek.org

activities, and creating a new business do not capture this modern understanding. Entrepreneurship is studied from multiple dimensions which provide many variants of the concept. It is nonetheless assumed that the underlying meaning is constant.

\subsection{Implications of perceptions of entrepreneurship}

The perceptions of entrepreneurship reviewed constitute knowledge which informs what is undertaken as entrepreneurship. If entrepreneurship is perceived as self-employment in an economy, policy and support programmes will focus on encouraging self-employment. If individuals perceive entrepreneurship as self-employment, indulging in micro small enterprising will constitute entrepreneurship even though innovations are not carried out. Similarly, if institutions of higher education perceive entrepreneurship as self-employment, curriculum will focus on preparing graduates for self-employment. However, not all self employed individuals undertake entrepreneurship, the creation of innovations, and thereby Henrekson and Sanandaji (2014) argue against using self-employment synonymously with entrepreneurship.

Similarly, the perception of entrepreneurship as creation of a new business has policy emphasis on support for start-ups. The disadvantage is the narrow viewpoint in that corporate entrepreneurship is often not emphasised upon in MSME policy and support initiatives. The creation of other categories of innovations is disregarded too. The perception does not help to focus on creation of enterprises with the most contribution towards economic growth as in most cases support is directed towards subsistence oriented enterprises. The perception of entrepreneurship as carrying out innovations on the other hand, puts much emphasis on creation of new knowledge which underlies the introduction of new values into the market. Schumpeter's (1934) theory has emphasis on spontaneous and discontinuous innovative change which brings new disequilibrium. Although he acknowledges that economic growth may in time, originate from continuous adjustments in small steps, Schumpeter (1934) refers only to pioneering innovations when talking about entrepreneurship of productive means. He thereby aligns entrepreneurship with creation of pioneering innovations only (Coccia, 2006). This theory would mean more emphasis on research and development. However, since pioneering innovations are fewer and far apart than incremental innovations (Audretsch, 2012), entrepreneurship, as creation of either incremental or pioneering innovations would bring economic benefits on a wider scale in developing countries. As such in this study innovation is perceived as either incremental or pioneering (Coccia, 2006).

This brief review shows that perceptions of entrepreneurship would have implications on activities undertaken and therefore affect economic results to be achieved.

\subsection{Perceptions and entrepreneurship in developed countries}

Studies on entrepreneurship are concentrated in developed and transition countries. As noted earlier, entrepreneurship is commonly defined as creation of a new business, enterprise or organisation (Scarborough, 2013; Dollinger, 2008). Burns (2016) distinguishes new enterprises created in the economy into two categories based on their growth orientation. These categories are lifestyle enterprises and growth enterprises. Lifestyle enterprises are created to support lifestyles of entrepreneurs whereas growth enterprises are created with ambition for growth (Burns, 2016). Organisation for Economic Cooperation and Development (OECD, 2010) defines high growth enterprises (HGEs) as enterprises with average annualised growth of greater than 20 percent per annum over a three year period, and with ten or more employees at the beginning of the observation period. Growth is measured using the number of employees, turnover or both. It is HGEs which, in most cases, introduce innovations and as such there is growing realisation in developed countries of the importance of growth enterprises as the microeconomic foundation of economic growth (Audretsch, 2012). It is HGEs which manifest 


\section{INTERNATIONAL JOURNAL OF ENTREPRENEURIAL KNOWLEDGE}

Issue 9, volume 2, ISSN 2336-2960 (Online)

www.ijek.org

Schumpeterian entrepreneurship and therefore entrepreneurship development policy in OECD countries focuses on enhancing innovation and growth among enterprises (OECD, 2019).

On the prevalence of entrepreneurship, Global Entrepreneurship Monitor (GEM, 2018) found low TEA rates in developed countries but when entrepreneurship is measured through prevalence of new firms, which introduce innovations, then it is higher in developed countries than in developing countries (Munemo, 2012). Furthermore, studies found that entrepreneurship positively contributes towards economic growth and new jobs in developed countries and not in developing countries (Decker et al., 2014; Stam \& van Stel, 2009). It is important to remember that carrying out innovations is at the centre of economic development theory (Schumpeter, 1934). The fact that despite high TEA rates, entrepreneurship does not contribute towards economic growth in developing countries (Zaki \& Rashid, 2016; Stam \& van Stel, 2009), it means there is lack of entrepreneurial behaviour which creates innovations in developing countries. Shane (2009) observed that not all MSMEs are entrepreneurial and therefore one of the key differences between entrepreneurship in developed and developing countries is the level of innovation.

This review demonstrates that perceiving entrepreneurship through Schumpeter's (1934) theory guides policy in OECD countries to focus on enhancing innovation and growth among enterprises (OECD, 2019). In OECD (2010; 2019) policy and programmes focus on the following: (1) improving the business environment to remove obstacles to growth and addressing disincentives to growth present in the regulation. (2) Encouraging entrepreneurial attitude for more growth ambition among entrepreneurs and MSMEs. (3) Supporting provision of training in order to help entrepreneurs and MSMEs cope with pressures that come with enterprise growth. (4) Improving access to debt and equity finance, and support to research and development that stimulates enterprise innovation, and (5) promoting innovation and internationalisation which enhances firm growth (OECD, 2010; 2019). In this case, the understanding of entrepreneurship in Schumpeterian sense guides development initiatives to support innovation that would ignite economic growth. Therefore entrepreneurship contributes towards economic growth in developed countries because there is higher prevalence of enterprises which carry out innovations (Munemo, 2012).

There is knowledge about high TEA rates in developing countries (GEM, 2018) but there is lack of knowledge about perceptions of entrepreneurship, types and rates of entrepreneurial activities undertaken and innovations created (Sheriff et al., 2016). As such it is challenging to reflect on the relationships among these concepts and economic growth. Lack of country context knowledge of entrepreneurship in developing countries makes it difficult to guide policy towards support of innovation through education and training, entrepreneurship finance, infrastructure development and regulation. Therefore MSME policies in some developing countries in Sub Saharan Africa, Malawi in particular, focus on general improvements in the environments for business. Nonetheless, the effort does not result in improved performance of MSMEs and their contribution towards economic growth and new jobs (Meressa, 2020; Cassim et al., 2014). There is therefore a need to understand country context knowledge about entrepreneurship in developing countries in order to determine the relationships among perceptions, entrepreneurial activities undertaken, innovations carried out and economic growth so that entrepreneurship development initiatives are informed accordingly.

\section{METHODOLOGY}

The purpose of the study was to measure perceptions of entrepreneurship in enterprises in Malawi in order to have country context knowledge of the concept which guides what is undertaken as entrepreneurship. A cross sectional survey of enterprises was undertaken in three cities (Blantyre, 


\section{INTERNATIONAL JOURNAL OF ENTREPRENEURIAL KNOWLEDGE}

Issue 9, volume 2, ISSN 2336-2960 (Online)

www.ijek.org

Lilongwe and Mzuzu) and three rural growth centres (Jenda, Monkey Bay and Thekerani) across the three regions of the country between May, 2020 and July, 2020.

There are approximately 1.6 million MSMEs in Malawi (Finscope, 2019). The study adopted 384 enterprises as an appropriate study sample (Saunders et al., 2009, p.219). There is no data base of all MSMEs in Malawi and therefore non probability sampling approaches were used. Cities constituted 75 percent of the sample and rural growth centres, 25 percent, on the rule of the thumb principle. Cities have the largest concentration of enterprises in the country whereas rural growth centres are being established in selected rural areas to spur economic development and have fewer enterprises. However, in each location, the first enterprise was randomly selected among the first three enterprises and thereafter every third enterprise was sampled without replacement in order to ensure unbiased selection of participants. Enterprise owners and managers were the key respondents in the study.

A questionnaire was used to collect responses in face to face interviews. In the first section, respondents details (sex, age, education and position), and enterprise details (type of ownership, year started, motivation for establishment, objective of enterprise, current number of employees and number of employees one year ago) were collected. These details were used to classify enterprises. In the second section, respondents were asked to define or explain how they understood the term entrepreneurship from the top of their minds, and further explain or list the activities their enterprises had undertaken which were considered entrepreneurial. Top-of-the-mind definition approach was applied which collects unaided responses from the top of the respondent's mind that are free from predetermined descriptions, definitions or expressions. Lee (2011) asserts that unaided responses help the practitioner to understand the concept in respondent's own language and thereby augment the existing understanding of the concept. In the third section of the questionnaire, respondents were requested to provide; (1) asset book values of their enterprises and their current liabilities position, (2) new products the enterprises created and introduced into the market over the past one year together with market exchange values realised. (3) New methods of production created over the past one year and their investment values, and (4) new markets entered by the enterprises over the past one year together with product exchange values realised. These details were collected in order to calculate present worth of new enterprises, values of new products and new methods of production created and value of new markets. Data collected covered the financial year starting April, 2019 to March, 2020.

A new enterprise was defined as the one which was less than three and half years old (Bosma et al., 2012) and its present worth was considered its value (Miciula et al., 2020). A new product was defined as the 'one with which customers are not yet familiar' (Schumpeter, 1934, p.66) and it included improved, imitated or entirely new products developed through research and development efforts (Kotler \& Armstrong, 2012). Exchange value realised when the product is sold, was considered its value (Bowman \& Ambrosini, 2003). A new method of production was defined as the 'one not yet tested by experience in the branch of manufacture concerned, which by no means be founded upon a discovery scientifically new, and can also exist in a new way of handling a commodity commercially' (Schumpeter, 1934, p.66). Its investment value was considered it value. A new market was defined as the 'one into which a particular branch of manufacture of a country in question has not previously entered, whether or not this market has existed before' (Schumpeter, 1934, p.66). Exchange values realised from the new market were considered its value (Bowman \& Ambrosini, 2003). The questionnaire was piloted in Mzuzu City before the commencement of the study. Analyses of definitions, descriptive statistics (frequencies) and comparison of mean values were undertaken to analyse the data collected. Definitions and the activities considered entrepreneurial were used to draw out the perceptions of entrepreneurship among enterprises in Malawi. Descriptive statistics and comparison of mean values were used to determine the categories of innovation which were carried out by enterprises studied in order to determine actual entrepreneurial activities undertaken. 
INTERNATIONAL JOURNAL OF ENTREPRENEURIAL KNOWLEDGE

Issue 9, volume 2, ISSN 2336-2960 (Online)

www.ijek.org

\section{RESULTS AND DISCUSSION}

A total of 337 enterprises participated in the study representing 88 percent of the targeted sample size. Descriptive statistics of the study sample are presented in Table 1. Respondents comprised 79.8 percent male and 20.2 percent female. The majority were aged between 16 and 45 years and were either owner $(74.5 \%)$ or manager $(25.5 \%)$ of enterprises studied. The over 55 year olds were the least represented at 8.6 percent of the sample. It is noteworthy that 84.6 percent of the respondents had at a minimum secondary school education. The analysis showed that 33 percent of enterprises were in the micro and small size categories for over 10 years denoting that some enterprises in Malawi do not achieve growth and remain permanently small. The sample reflects Finscope's (2019) highlight of the MSME sector in Malawi. The majority of MSMEs are micro enterprises, necessity motivated, profit oriented and sole proprietorship enterprises. This is against the background of high levels of poverty and unemployment in the country. The sole proprietorship enterprises operated predominantly in the informal sector.

Table 1 Composition of study sample

\begin{tabular}{|c|c|c|c|c|}
\hline No & Detail & Category & Frequency & Percent \\
\hline \multicolumn{5}{|c|}{ Respondents details } \\
\hline 1. & Sex & $\begin{array}{l}\text { Male } \\
\text { Female }\end{array}$ & $\begin{array}{c}269 \\
68\end{array}$ & $\begin{array}{l}79.8 \\
20.2\end{array}$ \\
\hline 2. & Age group & $\begin{array}{l}16-35 \\
36-45 \\
46-55 \\
\text { Over } 55\end{array}$ & $\begin{array}{c}154 \\
93 \\
61 \\
29\end{array}$ & $\begin{array}{c}45.7 \\
27.6 \\
18.1 \\
8.6\end{array}$ \\
\hline 3. & Education & $\begin{array}{l}\text { Secondary school } \\
\text { Graduate (technical college) } \\
\text { Primary school } \\
\text { Postgraduate }\end{array}$ & $\begin{array}{c}185 \\
89 \\
52 \\
11\end{array}$ & $\begin{array}{c}54.9 \\
26.4 \\
15.4 \\
3.3 \\
\end{array}$ \\
\hline 4. & Position of respondent & $\begin{array}{l}\text { Owner of business } \\
\text { Manager }\end{array}$ & $\begin{array}{c}251 \\
86\end{array}$ & $\begin{array}{l}74.5 \\
25.5\end{array}$ \\
\hline \multicolumn{5}{|c|}{ Enterprise details } \\
\hline 1. & Ownership of enterprise & $\begin{array}{l}\text { Sole proprietorship } \\
\text { Limited liability enterprise }\end{array}$ & $\begin{array}{c}318 \\
19\end{array}$ & $\begin{array}{c}94.4 \\
5.6\end{array}$ \\
\hline 2. & Age of enterprise & $\begin{array}{l}\text { Old (above } 3.5 \text { years old) } \\
\text { New (up to } 3.5 \text { years old) }\end{array}$ & $\begin{array}{c}243 \\
94\end{array}$ & $\begin{array}{l}72.1 \\
27.9\end{array}$ \\
\hline 3. & Motivation for establishment & $\begin{array}{l}\text { Necessity-motivated } \\
\text { Opportunity-motivated }\end{array}$ & $\begin{array}{c}273 \\
64\end{array}$ & $\begin{array}{l}81 \\
19\end{array}$ \\
\hline 4. & Objective of enterprise & $\begin{array}{l}\text { Profit making } \\
\text { Non-profit making }\end{array}$ & $\begin{array}{c}325 \\
12 \\
\end{array}$ & $\begin{array}{c}96.4 \\
3.6 \\
\end{array}$ \\
\hline 5. & $*$ Size of enterprise & $\begin{array}{l}\text { Micro enterprise } \\
\text { Independent/Self employed } \\
\text { Small enterprise } \\
\text { Medium enterprise } \\
\text { Large enterprise }\end{array}$ & $\begin{array}{c}157 \\
98 \\
71 \\
9 \\
2 \\
\end{array}$ & $\begin{array}{c}46.6 \\
29.1 \\
21.1 \\
2.7 \\
0.6 \\
\end{array}$ \\
\hline 6. & $\begin{array}{l}\text { Growth orientation of } \\
\text { enterprise }\end{array}$ & $\begin{array}{l}\text { Subsistence oriented } \\
\text { Growth oriented }\end{array}$ & $\begin{array}{c}330 \\
7\end{array}$ & $\begin{array}{c}97.9 \\
2.1\end{array}$ \\
\hline
\end{tabular}

(Source: Own research) 


\section{INTERNATIONAL JOURNAL OF ENTREPRENEURIAL KNOWLEDGE}

Issue 9, volume 2, ISSN 2336-2960 (Online)

www.ijek.org

*Enterprise size classification based on Government of Malawi (2012): Independent/self employed $=0$ employees, micro enterprise $=1-4$ employees, small enterprise $=5-20$ employees, medium enterprise $=21-100$ employees and large enterprise $=100+$ employees

On perceptions of entrepreneurship, Table 2 presents a sample of definitions of entrepreneurship from respondents. Analyses of the definitions showed that entrepreneurship was related to creation of jobs $(16.3 \%)$, managing of one's own business $(15.4 \%)$, starting one's own business $(11 \%)$, a business $(8.3 \%)$, self-employment $(5.6 \%)$ and small and medium enterprises $(3 \%)$. The other perceptions of entrepreneurship constituted 4.2 percent of the responses and they included networking, making new products, creating innovations, developing the local area, government business support programmes, empowerment, selling your ideas and doing work with one's own hands. However, 36.2 percent of the respondents did not know the definition of entrepreneurship. The majority of these respondents had primary school education (81\%) although 8 percent of graduates also failed to define entrepreneurship. The results nonetheless showed that entrepreneurship has a strong connotation with enterprise as starting and managing one's own business with an emphasis on making profit and creating jobs in the economy.

\section{Table 2 Sampled definitions of entrepreneurship from respondents}

\begin{tabular}{|l|l|}
\hline No & Entrepreneurship is: \\
\hline 1 & a business that generates income \\
\hline 2 & a form of business which helps in creating employment \\
\hline 3 & ability to organize a business venture and assume the risk for it \\
\hline 4 & act of starting a business while taking risks with the hope of making profits \\
\hline 5 & $\begin{array}{l}\text { art of recognizing an opportunity that can generate income while helping the country deal } \\
\text { with challenges it faces }\end{array}$ \\
\hline 6 & coming up with ideas and turning them into business \\
\hline 7 & creating good products or services \\
\hline 8 & creating innovations in business \\
\hline 9 & creating jobs \\
\hline 10 & $\begin{array}{l}\text { development of vision and associated implementation plans to provide goods or services } \\
\text { in selected markets }\end{array}$ \\
\hline 11 & doing business one after another \\
\hline 12 & empowerment through business \\
\hline 13 & encouraging start-ups \\
\hline 14 & government programme to support businesses \\
\hline 15 & independence in doing what you want to earn a living \\
\hline 16 & individuals with ideas who develop a business using experience and skills \\
\hline 17 & initiative to start a new business venture usually from scratch \\
\hline 18 & innovative management of business \\
\hline 19 & making products \\
\hline 20 & managing a business profitably \\
\hline 21 & managing own business for profit regardless of risks \\
\hline 22 & managing own business with creative ideas \\
\hline 23 & modern name for business \\
\hline 24 & networking \\
\hline 25 & new name for doing business \\
\hline 26 & owning a business small or large \\
\hline 27 & owning a business that employ others \\
\hline 28 & owning a business that returns income \\
\hline 29 & process of designing and running a new business by owner \\
\hline
\end{tabular}


INTERNATIONAL JOURNAL OF ENTREPRENEURIAL KNOWLEDGE

Issue 9, volume 2, ISSN 2336-2960 (Online)

www.ijek.org

\begin{tabular}{|l|l|}
\hline 30 & $\begin{array}{l}\text { process of designing, launching and running a new business and taking on financial risks } \\
\text { to make profit }\end{array}$ \\
\hline 31 & process of starting and managing own business \\
\hline 32 & self employment \\
\hline 33 & small and medium enterprises \\
\hline 34 & starting own business \\
\hline 35 & turning new ideas into new products in business \\
\hline 36 & unity in different works \\
\hline 37 & working with one's own hands \\
\hline
\end{tabular}

(Source: Own research)

On activities undertaken by enterprises of which participants perceived were entrepreneurial, the results showed that 19.6 percent considered the enterprise owned as the embodiment of entrepreneurial activities. Creating jobs was considered the entrepreneurial activity by 15.7 percent of the respondents and 9.5 percent felt they had not carried out any activities that would be classified as entrepreneurship per se. A larger proportion of respondents $(43.3 \%)$ did not know which activities undertaken by their enterprises were entrepreneurial whereas 11.9 percent considered being self employed and the various activities conducted in normal day to day running of the enterprises were entrepreneurial activities. Therefore, the study found that creating new enterprises, creating jobs and all activities undertaken in day to day management of an enterprise were considered entrepreneurial activities. The activities considered entrepreneurial reflect the respondents' perceptions of the meaning of entrepreneurship. Table 3 presents a summary of analyses on innovations carried out by enterprises studied.

\section{Table 3 Innovations undertaken and their mean values}

\begin{tabular}{|c|c|c|c|c|c|c|c|}
\hline \multicolumn{9}{|c|}{ Innovations and their mean values (US\$) } \\
\hline \multicolumn{2}{|c|}{ New enterprises } & \multicolumn{2}{|c|}{ New products } & $\begin{array}{c}\text { New methods of } \\
\text { production }\end{array}$ & \multicolumn{2}{c|}{ New markets } \\
\hline $\begin{array}{c}\text { Frequency } \\
\text { (Percent) }\end{array}$ & Mean & $\begin{array}{c}\text { Frequency } \\
\text { value }\end{array}$ & $\begin{array}{c}\text { Mean } \\
\text { (Percent) }\end{array}$ & $\begin{array}{c}\text { Frequency } \\
\text { value } \\
\text { (Percent) }\end{array}$ & $\begin{array}{c}\text { Mean } \\
\text { value } \\
\text { US\$ }\end{array}$ & $\begin{array}{c}\text { Frequency } \\
\text { (Percent) }\end{array}$ & $\begin{array}{c}\text { Mean } \\
\text { value } \\
\text { US\$ }\end{array}$ \\
\hline $94(28 \%)$ & 8,874 & $84(25 \%)$ & 12,003 & $7(2 \%)$ & 1,719 & $4(1.2)$ & 1,420 \\
\hline
\end{tabular}

(Source: Own research)

The results showed that few enterprises carried out innovations and the values of innovations carried out were low. At least 25 percent of the enterprises created new products but new methods of production and new markets were the least undertaken innovations within Schumpeter's (1934) classification.

Overall, the results showed that MSMEs in Malawi understood entrepreneurship as starting, managing or running of one's own business with making profit as the main objective. Ownership of an enterprise comes out as a salient point in explaining entrepreneurship. Therefore starting a business, creating jobs, day to day activities involved in running a business and undertaking any self-employment are considered entrepreneurial activities. However, there is low innovation among enterprises especially in the creation of new markets and new methods of production.

The understanding of entrepreneurship found in the study can be grounded in classical economic theories (Cantillon, 1755; Say, 1816). It was reviewed that entrepreneurship in Cantillon's (1755) theory focuses on profit making. Entrepreneurs identify market discrepancies and undertake risks to procure raw 


\section{INTERNATIONAL JOURNAL OF ENTREPRENEURIAL KNOWLEDGE}

Issue 9, volume 2, ISSN 2336-2960 (Online)

www.ijek.org

materials at certain prices in order to rework them up and resell at uncertain prices for a profit. Say (1816) on the other hand, theorizes entrepreneurship as the coordination of factors of production to produce goods and services. Following Say's (1816) theory, Scarborough (2013), Dollinger (2008), and other scholars define entrepreneurship as the creation or founding of a new organisation or business. Therefore, the perceptions of entrepreneurship as starting and managing or running of one's own business with profit as the main objective found in the study can be grounded in these early theories. However, the prevailing perceptions do not align with the modern concept understanding, which focuses on innovative change and puts entrepreneurship at the centre of economic development theory. The fact that most MSMEs did not perceive entrepreneurship as undertaking innovations and that they did not carry out innovations may not be a mere coincidence.

This is an area of interest where perceptions of entrepreneurship would be presumed to guide policy differently between Malawi and OECD countries. In OECD countries, the policy focuses on MSME innovation and growth (OECD , 2019) because entrepreneurship is perceived as carrying out innovations, and it is considered the microeconomic foundation for economic growth (Audretsch, 2012). Entrepreneurship is considered a strategy for economic development in Malawi since the 1980s (Masten \& Kandoole, 1997). Support is directed towards start-ups and self-employment initiatives against the background of high unemployment and poverty levels. The implied meaning of entrepreneurship is starting and managing one's own business for profit, as found in the study. It could be deduced that the understanding of entrepreneurship is behind policy direction in both contexts of Malawi and OECD countries. The perceptions of entrepreneurship in Malawi are inadequate to guide economic development because of the lack of emphasis on undertaking innovations. The findings demonstrate that understanding a concept is important in practice. As efforts are being directed towards correcting the binding constraints in the environment for business, correcting the perceptions of entrepreneurship is pertinent in the country. It is recommended that stakeholders in entrepreneurship development review their knowledge about entrepreneurship and align with theories where entrepreneurship is the driver of business growth and economic development. Entrepreneurship must be grounded in Schumpeter's (1934) theory as carrying out innovations and not just starting and managing an enterprise because not all enterprises are entrepreneurial (Shane, 2009).

\section{CONCLUSIONS}

The purpose of the study was to measure the perceptions of entrepreneurship in enterprises in Malawi to have country context knowledge of the concept that guides what is undertaken as entrepreneurship. A cross-sectional survey of 337 enterprises in three cities and three rural growth centres revealed that starting and managing one's own business for profit, creating jobs, and being self-employed is the prevailing understanding of entrepreneurship in Malawi. This, seemingly, is the understanding that guides policy towards supporting start-ups and self-employment in the country. Although the perceptions found can be grounded in classical economic theories, they are deemed inadequate to ignite economic development because of a lack of focus on innovation. Entrepreneurship at the centre of economic development theory is carrying out innovations: new products, new methods of production, new sources of supply of raw materials, new markets, and new ways of organisation of any industry. The findings posit that understanding a concept is important in practice. Therefore concepts such as entrepreneurship which have multiple perceptions or theories, require appropriate knowledge to guide policy and development initiatives in order to achieve expected results. It is thereby recommended that stakeholders in entrepreneurship development appraise their knowledge about entrepreneurship to align with theories where entrepreneurship is the driver of business growth and economic development.

The study has contributed country context understanding of entrepreneurship in Malawi in a bid to fill knowledge gaps about entrepreneurship in developing countries, especially in Sub-Saharan Africa. The 


\section{INTERNATIONAL JOURNAL OF ENTREPRENEURIAL KNOWLEDGE}

Issue 9, volume 2, ISSN 2336-2960 (Online)

www.ijek.org

findings are nonetheless limited for understanding the regional knowledge context because only one country was involved. Therefore further research is required in other developing countries on the relationships between (1) perceptions of entrepreneurship and entrepreneurial activities undertaken by MSMEs, and (2) entrepreneurial activities undertaken and economic development. These studies would inform policy on the general context of entrepreneurial behaviour, entrepreneurial activities that require support, and business environments to create in order to support innovation in MSMEs in the region. This is necessary because improvements have been undertaken in environments for business for decades in most developing countries, but economic growth and the creation of quality jobs are never attained. As such, a closer look at what MSMEs do is pertinent.

\section{REFERENCES}

Acs, Z., \& Virgill, N. (2009). Entrepreneurship in developing countries. Jena Economic Research Papers, No. 2009, 023, Friedrich Schiller University, Jena and Max Planck Institute of Economics. Jena.

Audretsch, D. B. (2012). Determinants of high growth entrepreneurship. Report prepared for the OECD/DBA International Workshop on High growth firms: Local policies and local determinants, $28^{\text {th }}$ March, 2012.

Bosma, N., Coduras, A., Litovsky, Y., \& Seaman, J. (2012). GEM Manual: A report on the design, data and quality control of the Global Entrepreneurship Monitor. GEM Consortium.

Bowman, C., \& Ambrosini, V. (2003). What does value mean and how is it created, maintained and destroyed? Academy of Management Annual Meeting, Seattle, Washington, 1-6 August.

Bula, H. O. (2012). Evolution and theories of entrepreneurship: A critical review on the Kenyan Perspective. International Journal of Business and Commerce, 1(11), 81-96.

Burns, P. (2016). Entrepreneurship and small business start-up, growth and maturity (4 ${ }^{\text {th }}$ Ed). Palgrave.

Cantillon, R. (1755). Essay on the Nature of Trade in General. London: Henry Higgs (edition and translation 1959).

Cassim, S., Soni, P., \& Karodia, A. (2014). Entrepreneurship policy in South Africa. Arabian Journal of Business and Management Review, 3(9), 29-43.

Chen, C. C. (2014). Entrepreneurship, economic growth and employment: A case study of Taiwan. Hitotsubashi Journal of Economics, 55, 71-88.

Coccia, M. (2006). Classifications of innovations survey and future directions. Ceris-cnr Working Paper Anno 8, No. 2, National Research Council of Italy.

Dalious, M., Mandere, G., Jamali-Phiri, M., \& Kaneka, B. (2012). Global entrepreneurship monitor Malawi report 2012. Global Entrepreneurship Research Association, UK.

Decker, R., Haltiwanger, J., Jarmin, R., \& Miranda, J. (2014). The role of entrepreneurship in US job creation and economic dynamism. The Journal of Economic Perspectives, 28(3), 3-24.

Dollinger, M. J. (2008). Entrepreneurship strategies and resources (4 ${ }^{\text {th }}$ edition). Marsh Publications, Lombard, Illinois, USA.

Finscope (2019). Micro, small and medium enterprises survey, Malawi. Finmark Trust.

Global Entrepreneurship Monitor (2018). Global Entrepreneurship Monitor Global Report 2017-2018, Wellesley, MA, Babson College.

Government of Malawi (2017a). Economic development document for Malawi. Ministry of Finance Economic Planning and Development, Lilongwe, Malawi.

Government of Malawi (2017b). Malawi growth and development strategy: Building a productive, competitive and resilient nation. Lilongwe, Malawi.

Government of Malawi (2012). Micro small and medium enterprises (MSME) policy strategy for the Republic of Malawi. Prepared by Chris Darroll, SBP, Johannesburg, South Africa.

Harbison, F. (1956). Entrepreneurial organisation as a factor in economic development. Quarterly Journal of Economics. 


\section{INTERNATIONAL JOURNAL OF ENTREPRENEURIAL KNOWLEDGE}

Issue 9, volume 2, ISSN 2336-2960 (Online)

www.ijek.org

Henrekson, M., \& Sanandaji, T. (2014). Small business activity does not measure entrepreneurship. National Academy of Sciences, 111(5), 1760-1765.

Kirby, D. (2003). Entrepreneurship. McGraw-Hill.

Kirzner, I. (1973). Competition and Entrepreneurship, Chicago: University Press, Chicago.

Kotler, P., \& Armstrong, G. (2012). Principles of Marketing, $14^{\text {th }}$ Edn. Pearson Prentice Hall.

Kozubíková L., \& Zoubková A. (2016), Entrepreneur's attitude towards innovativeness and competitive aggressiveness: the case study of Czech micro-enterprises, Journal of International Studies, Vol. 9, No 1, pp. 192-204.

Lafuente, E., Acs, Z., \& Szerb, L. (2018). The entrepreneurship paradox: More entrepreneurs are not always good for the economy- The role of the entrepreneurial ecosystem on economic performance in Africa. SSRN Working Paper Series.

Lee, C. J. (2011). Understanding bank service quality in customers' terms: an exploratory analysis of topof-mind definition. International Journal of Business and Social Sciences, 2(21).

Masten, J., \& Kandoole, B. (1997). The capacity of small and medium enterprises support in Malawi to support small business expansion. Lilongwe, Malawi: Malawi Institute of Management.

Meressa, H. A. (2020). Growth of micro and small scale enterprises and its driving factors: Empirical evidence from entrepreneurs in emerging region of Ethiopia. Journal of Innovation and Entrepreneurship, 9(11), 1-22.

Miciula, I., Kadlubek, M., \& Stepien, P. (2020). Modern methods of Business Valuation - Case study and new concepts. Sustainability, 12, 1-22.

Munemo, J. (2012). Entrepreneurship in developing countries: Is Africa different? Journal of Developmental Entrepreneurship, 17(1), 1-12.

Nitu-Antonie, R. D., Feder, E. S., \& Munteanu, V. P. (2017). Macroeconomic effects of entrepreneurship from an international perspective. Sustainability, 9, 1159.

Organisation for Economic Cooperation and Development (2019). OECD SME and Entrepreneurship Outlook: Policy Highlights. OECD.

OECD (2010). High growth enterprises: What governments can do to make a difference? OECD Studies on SMEs and entrepreneurship, Organisation for Economic Cooperation and Development, Paris.

Ruchkina, G., Melnichuk, M., Frumina, S., \& Mentel, G. (2017). Small and medium enterprises in regional development and innovations. Journal of International Studies, 10(4), 259-271.

Saunders, M., Lewis, P., \& Thornhill, A. (2009). Research methods for business students, $5^{\text {th }}$ Edition. Prentice Hall.

Say, J. A. (1816). A Treatise on Political Economy. London: Sherwood, Neeley and Jones.

Scarborough, N. (2013). Essentials of entrepreneurship and small business management, Sixth Edn. Pearson.

Schumpeter, J. A. (1934). The theory of economic development. Cambridge, MA: Harvard Economic Studies.

Shane, S. (2009). Why encouraging more people to become entrepreneurs is bad public policy. Small Business Economics, 33(2): 141-149.

Shane, S., \& Venkataraman, S. (2000). The promise of entrepreneurship as a field of research. Academy of management review, 25(1), 217-226.

Sheriff, M., Muffatto, M., \& Cooper, S. (2016). Measuring entrepreneurship environments in Africa: challenges in using international reports. International Journal of Entrepreneurship and Innovation Management, 20 (1/2), 20-44.

Stam, E., \& van Stel, A. (2009). Types of entrepreneurship and economic growth. Research paper 2009/47, UNU---Wider, Helsinki.

van Stel, A., Carree, M., \& Thurik, R. (2005). The effect of entrepreneurial activity on national economic growth. Small Business Economics, 24(3), 311-321.

World Bank Group (2020). Doing business 2020: Comparing business regulation in 190 economies. Washington, DC: World Bank Group.

Zaki, I. M., \& Rashid, N. H. (2016). Entrepreneurship impact on economic growth in emerging countries. The Business and Management Review, 7(2), 31-39. 
INTERNATIONAL JOURNAL OF ENTREPRENEURIAL KNOWLEDGE

Issue 9, volume 2, ISSN 2336-2960 (Online)

www.ijek.org

\section{BRIEF DESCRIPTION OF AUTHOR:}

\section{Charles Mwatsika}

ORCID ID: https://orcid.org/0000-0001-7390-2847

Management Studies Department, Faculty of Commerce, Malawi University of Business and Applied Sciences, Private Bag 303, Blantyre 3, Malawi. www.mubas.ac.mw

Email: cmwatsika@mubas.ac.mw

Charles Mwatsika is a lecturer in entrepreneurship, tourism, and corporate strategy with the Malawi University of Business and Applied Sciences. His research interests are enterprise start-ups, enterprise growth, entrepreneurship development in Sub-Saharan Africa, and pro-poor tourism for economic development in developing countries. 